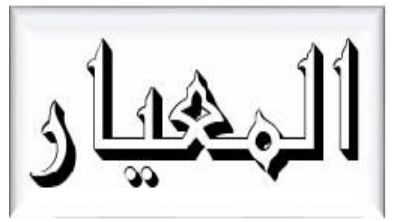

Al Mi'yar

Vol. 4, No. 2, Oktober 2021

P-ISSN: 2620-6749, E-ISSN: 2620-6536

DOI: $10.35931 / \mathrm{am} . v 4 \mathrm{i} 2.668$

Naskah diterima: 22-07-2021

Direvisi: 02-10-2021

Disetujui: 08-10-2021

\title{
TĀJUL LUGHATI: DESAIN MEDIA PEMBELAJARAN ONLINE
}

\author{
Hani'atul Mabruroh', Fairuz Subakir'2, Riza Nurlaila ${ }^{3}$, Naufal Akmal Syammary $^{4}$ \\ 1,2,3,4Universitas Darussalam Gontor, Jawa Timur, Indonesia \\ Email: haniatul.mabruroh@unida.gontor.ac.id, fairuzsubakir01@gmail.com, \\ rizanurlaila@unida.gontor.ac.id,naufalakmal@mhs.unida.gontor.ac.id
}

\section{Abstract}

This study aims to provide Arabic language learning solutions based on website that can be applied in Arabic language learning during the covid-19 pandemic. This is based on Arabic language learning for students in UNIDA Gontor schools experiencing a decrease in quantity and quality. The long-lasting pandemic resulted in Pusdiklat UNIDA Gontor vacuum from training, training for MTS equivalent at home or abroad. Therefore, website-based online learning is expected to provide solutions for Arabic language learning in the pandemic. This research uses the early stage of Research and Development method, where the process stops at product design without conducting trials of the product. This research data was obtained by observation, interview, questionnaire, and literature study. The result of this study is in the form of Arabic language learning media based on a website called "Taajul Lughati" which is an innovation of Arabic language learning media in which there are training materials, namely durushullughah al-arabiyah, maharatul qira'ah and maharatul 'istima'.

Keywords: Learning Media, Online, Website, Tājul Lughati

\section{PENDAHULUAN}

Bahasa Arab merupakan bahasa internasional yang eksis di berbagai belahan dunia. Hal ini dibuktikan dengan posisi bahasa Arab di Perserikatan Bangsa-Bangsa (PBB) yang telah menduduki posisi strategis di antara 
berbagai bahasa dunia internasional. ${ }^{1}$ Selain itu bahasa Arab juga telah menjadi materi pokok pelajaran di berbagai instansi pendidikan, salah satunya ialah di Indonesia. Namun kendati demikian, di Indonesia bahasa Arab belum menjadi bahasa yang banyak diminati oleh para pelajar. Adapun alasan yang sering kali muncul ialah karena metode, dan strategi pembelajaran yang dipakai kurang tepat ${ }^{2}$. Selain itu, penggunaan media pembelajaran yang kurang menarik dan terbatas pada buku ajar juga menjadi salah satu sebab rendahnya ketertarikan serta atensi siswa dalam pembelajaran bahasa Arab ${ }^{3}$. Problem inilah yang harus menjadi perhatian para pengajar bahasa Arab di berbagai instansi pendidikan Indonesia.

Terlepas dari permasalahan diatas, pada masa pandemi Covid-19 pembelajaran bahasa Arab berjalan dengan segala keterbatasan. Pembelajaran tidak dapat dilaksanakan secara konvensional (tatap muka) sehingga suasana kelas dalam pembelajaran daring cenderung formal serta terkesan membosankan. Salah satu faktor utamanya adalah guru, murid, dan orang tua yang kurang memahami dan mengikuti perkembangan media. Keadaan tersebut berdampak pada menurunya minat serta motivasi siswa dalam mempelajari bahasa Arab. ${ }^{4}$ Untuk mengatasi perkara tersebut guru diharapkan agar lebih kreatif dan inovatif dalam menyampaikan materi pelajaran, memilih metode, dan media pembelajaran yang tepat sasaran.

Hal serupa terjadi di Pusdiklat UNIDA Gontor. Beberapa diklat tertunda hingga batas waktu yang tidak terbatas dikarenakan merebaknya Covid-19. Hal ini memberikan dampak yang cukup besar. Diklat yang dilaksanakan setiap pekan, bulanan, atau per-semester, terpaksa ditunda. Berkenaan dengan perihal tersebut, di masa pandemi ini pusdiklat dapat memanfaatkan teknologi dalam keberlangsungan kegiatan pembelajaran. Pelatih dapat

1 Zulhannan, Teknik Pembelajaran Bahasa Arab Interaktif (Jakarta: Raja Grafindo Persada, 2014), h. 100.

${ }^{2}$ Hermawan Acep, Metodologi Pembelajaran Bahasa Arab (Bandung: Remaja Rosdakarya, 2011), h. 56.

3 Pangadilan Rambe, "Pengembangan Aplikasi Pembelajaran Inovatif Dalam Pembelajaran Bahasa Arab Berbasis Web”, Arabi : Journal of Arabic Studies, vol. 4, no. 1 (2019), h. 56.

${ }^{4}$ Amalia Firdausia, Imam Asrori, and Mohammad Ahsanuddin, "Pengembangan Media Pembelajaran Bahasa Arab Berbasis Web Offline”, Pendidikan Islam dan Keguruan, vol. 2, no. 2 (2020), h. 31. 
mengoptimalkan teknologi yang sederhana, tidak mengharuskan dengan teknologi canggih yang membutuhkan anggaran dan dana yang besar. Namun di sisi lain, pemanfaatan teknologi tersebut masih terbilang belum maksimal. Salah satu solusinya adalah pendidik atau pelatih dapat memanfaatkan teknologi berbasis website yang dapat mengkombinasikan antara teks, gambar, audio dan video menjadi sebuah media pembelajaran yang menarik. Dalam implementasinya website tersebut terbilang mudah dan terjangkau serta dapat didesain sesuai dengan materi-materi yang dibutuhkan dan tersedia. ${ }^{5}$ Melalui teknologi ini pendidik atau pelatih dapat menciptakan media pembelajaran yang sesuai dengan kebutuhan pengaajaran.

Dalam pembahasan ini penulis menemukan beberapa riset terdahulu yang relevan sehingga menjadi inspirasi bagi penulis dalam melaksanakan pengembangan yang akan dilakukan, antara lain ialah: Penelitian yang dilakukan oleh (1) Amalia Firdausia, dkk dengan judul "Pengembangan Media Pembelajaran Bahasa Arab berbasis Web Offline pada Siswa Kelas X SMA Negeri 8 Malang", 2020. (2) Penelitian Mahyudin Ritonga, dkk dengan judul "Pembelajaran Bahasa Arab Berbasis Teknologi Informasi dan Komunikasi di Kota Padang", 2016. (3) Penelitian Nuril Mufidah, dkk dengan judul "Hybrid Learning dalam Pembelajaran Kosa Kata Bahasa Arab pada Anak Berbantuan Media Al-Mutho", 2019.

Setelah melaksanakan studi kepustakaan atas penelitian terdahulu penulis menemukan perbedaan yang mendasar, diantaranya yaitu: (1) Riset yang dilakukan oleh peneliti sebelumnya ialah pembelajaran berbasis web offline (2) Pembelajaran bersifat pasif karena tidak adanya komunikasi dua arah, antara pendidik dan peserta didik (3) Konten materi pembelajaran yang tersedia hanya terbatas pada video. Berkenaan dengan hasil pustaka tersebut peneliti menganggap bahwa pengembangan media pembelajaran bahasa Arab di masa pandemi Covid-19 merupakan keharusan yang mutlak. Berlandaskan penelitian di atas, pada kesempatan ini penulis mencoba mengembangkan serta melengkapi kekurangan media pembelajaran bahasa Arab yang ada.

5 Muhammad Yaumi and Muljono Damopolii, "Model Integrasi Teknologi Informasi dan Komunikasi dalam", Al-Musannif: Journal of Islamic Education and Teacher Training, vol. 1, no. 2 (2019), h. 139. 
Peneliti mengembangkan media web online untuk pembelajaran jarak jauh. dengan menguraikannya pada makalah yang berjudul "Taajul Lughati: Solusi Pembelajaran Bahasa Arab Berbasis Website di Masa Pandemi Covid-19. Media pembelajaran yang akan dibuat mencakup dua level pembelajaran bahasa Arab dengan tingkatan beginner dan intermediate yaitu setingkat dengan siswa SD dan SMP sederajat. Media ini akan didukung dengan konten berupa audio, video, teks dan gambar yang menarik, dengannya diharapkan dapat meningkatkan motivasi serta minat siswa sehingga dapat mencapai hasil belajar yang baik. Melalui gagasan ini diharapkan dapat memberi jawaban atas problematika pembelajaran bahasa Arab di masa pandemi Covid-19. Hal ini juga merupakan upaya dalam mewujudkan pendidikan yang bermutu dan berkualitas sesuai dengan point keempat dari Sustainable Development Goals 2030 .

\section{METODE PENELITIAN}

Dalam penelitian ini, penulis menggunakan metode penelitian Research and Development tahap awal hingga proses desain produk. Produk yang dihasilkan berupa media pembelajaran online berbasis website. Teknik pengumpulan data yang digukanan adalah observasi, wawancara, angket, dan studi literatur. Observasi dilakukan terhadap pendidik/guru selama pembelajaran berlangsung sehingga diperoleh evaluasi dalam pembelajaran bahasa Arab online. Wawancara dilaksanakan terhadap guru, direktur Pudiklat, dan peserta didik untuk mengetahui kebutuhan materi bahasa Arab pada level pemula di Pusdiklat UNIDA Gontor. Angket diberikan kepada guru dan peserta didik untuk mengetahui evaluasi dari desain web. Data ini diperlukan untuk perbaikan desain. Peneliti melakukan studi literatur dari berbagai buku bahasa Arab untuk mendapatkan informasi terkait materi pembelajaran yang sesuai dengan kebutuhan peserta didik diklat. Cara ini digunakan untuk menelukan inovasi-inovasi baru seputar media pembelajaran online dan materi-materi yang akan diterapkan di dalamnya. Dalam analisa data, peneliti menggunakan metode Milles and Huberman untuk menganalisa data kualitatif. Metode ini terdiri dari 3 tahapan, yaitu pengumpulan data, pengumpulan data, dan kesimpulan. 
Langkah-langkah peelitian yang ditempuh peneliti dalam proses penelitian dan desain media pembelajaran online "Taajul Lughati" adalah sebagai berikut:

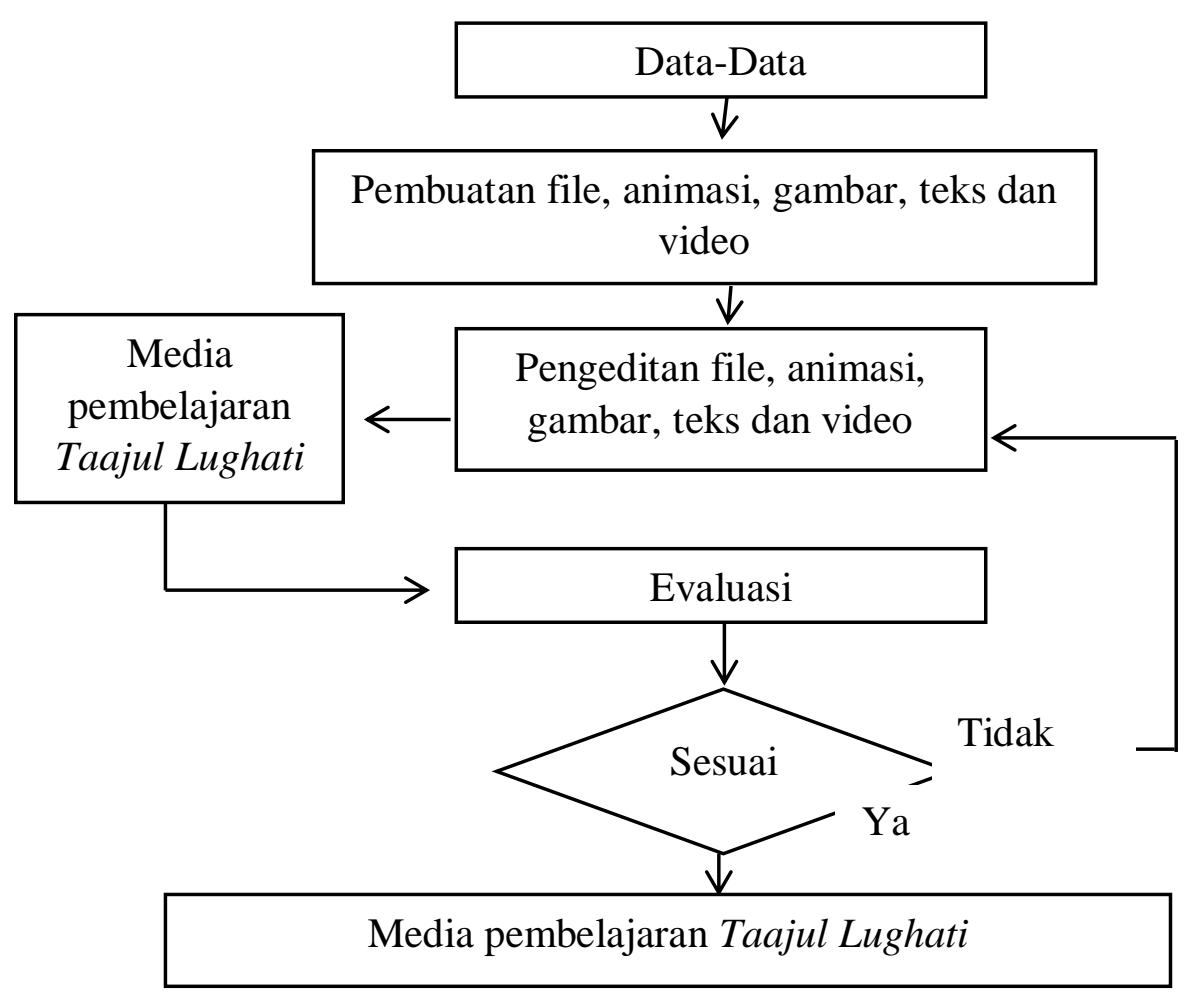

\section{PEMBAHASAN}

\section{Media Pembelajaran}

Kata media berasal dari bahasa latin dan merupakan bentuk jamak dari kata medium yang secara harfiah berarti perantara atau pengantar. ${ }^{6}$ Secara istilah media merupakan segala sesuatu yang dapat menjadi perantara informasi dari sumber informasi kepada penerima informasi. ${ }^{7}$ Media

6 Arief Sadiman, Media Pendidikan Pengertian, Pengembangan dan Pemanfaatnnya, (Jakarta: Rajawali, 2015), h. 6

7 Imam Falahudin, Pemanfaatan Media Pembelajaran, Jurnal Lingkar Widyaiswara, Vol. 1 no. 4, (2014), h. 106 
pembelajaran dapat berupa perangkat keras (hardware) dan perangkat lunak (software). Hardware adalah alat-alat yang dapat mengantar pesan seperti Over Head, Projector, radio, televisi, dan sebagainya. Sedangkan software ialah isi program yang mengandung pesan seperti informasi yang terdapat pada buku atau bahan cetak lainnya, dalam materi yang disuguhkan dalam bentuk bagan, grafik, diagram, dan lain sebagainya. ${ }^{8}$

Media pembelajaran tidak hanya dipandang sebagai alat bantu belaka bagi guru dalam mengajar, tetapi lebih sebagai penyalur pesan dari pemberi pesan (guru) kepada penerima pesan (siswa). Sebagai pembawa pesan, media tidak hanya digunakan oleh guru tetapi yang lebih penting lagi dapat juga digunakan oleh siswa. Sehingga sebagai penyaji dan penyalur pesan dalam hal-hal tertentu media dapat mewakili guru menyampaikan informasi secara lebih jelas, teliti, dan menarik. ${ }^{9}$ Maka dapat disimpulkan bahwa media tidak hanya sebagai alat perantara untuk mempermudah guru dalam meyampaikan bahan ajar, tetapi lebih dari itu yaitu untuk mencapai nilai-nilai yang belum tersampaikan sehingga seorang guru tertuntut untuk menginisiasikan suatu cara agar nilai-nilai dalam pembelajaran dapat tersampaikan dengan baik.

Pemilihan media yang tepat menghadirkan manfaat yang baik lagi guru dan murid. Pemilihan media pembelajaran dapat menjadikan materi yang lebih konkrit dan menarik, sehingga siswa dengan mudah memahami materi. Medi juga memudahkan guru dalam menyampaikan materi sehingga kualitas pembelajaran menjadi lebih baik. ${ }^{10}$ Di samping itu, media pembelajaran dapat memberikan stimulus siswa untum lebih semangat dalam belajar. Siswa akan lebih mudah memahami materi dan susasa pembelajaran tidak membosankan dikarenakan banyak kegiatan yang akan dilakukan siswa dalam kelas.

Peran dan fungsi media pembelajaran yang sangat besar, membuat pada guru maupun lembaga pendidikan mengambil langkah-langkah strategis dalam memilih media yang tepat guna. Pada dasarnya, tidak ada media yang

\section{h. 205}

8 Wina Sanjaya, Perencanaan dan Desain Sistem Pembelajaran, (Jakarta: Kencana, 2017),

9 Arief S. Sadiman, Dkk, Media Pendidikan: Pengertian, Pengembangan, dan Pemanfaatannya, Jakarta: Raja Grafindo Persada, (2015), h. 7

10 Siti Maemunawarti, dkk., Peran Guru, Orang Tua, Metode,dan Media Pembelajaran: Strategi KBM di Masa Pandemi Covid-19, (Serang: 3M Media Karya Serang,2020), h. 74 
dapat dikatakan paling bagus, efektif, dan efisien. Efektif atau efisien suatu media pembelajaran dilihat dari tujuan dan sasaran pembelajaran tertentu. Jadi, tidak ada masalah jika suatu lembaga melilih media tradisional maupun media teknologi mutakhir. ${ }^{11}$ Contoh dari media tradisonal adalah proyeksi overhead, slides, gambar, poster, rekaman, film, dan lain sebagainya. Sedangkan contoh media teknologi mutakhir adalah media berbasis telekominikasi, permainan komputer, sistem tutor intelejen, kuliah jarak jauh, dan lainnya. Banyak lembaga pendidikan yang memilih media tradisional dan berhasil menerapkan dalam pembelajaran secara efisien, namun banyak pula yang belum berhasil. Dalam hal ini, dapat disimpulkan bahwa pemanfaatan media dengan teknologi mutakhir belum menjamin keberhasilan dalam pembelajaran, karena keberhasilan dalan mencapai tujuan pembelajaran bukan hanya ketepatan dalam memilih media pembelajaran.

\section{Pembelajaran Online (E-Learning)}

Istilah E-Learning mengandung pengertian yang sangat luas, sehingga banyak pakar yang menguraikan tentang definisi E-Learning dari berbagai sudut pandang. Salah satu definisi yang cukup dapat diterima banyak pihak misalnya dari Darin E. Hartley yang menyatakan: E-Learning merupakan suatu jenis belajar mengajar yang memungkinkan tersampaikannya bahan ajar ke siswa dengan menggunakan media Internet, Intranet atau media jaringan komputer lain. ${ }^{12}$ E-learning juga dapat dikatakan sebagai kegiatan pembelajaran yang memanfaatkan jaringan (Internet, LAN, WAN) sebagai metode penyampaian, interaksi, dan fasilitasi serta didukung oleh berbagai bentuk layanan belajar lainnya. ${ }^{13}$

Pembelajaran online menerapkan konsep belajar jarak jauh dengan menggunakan teknologi informasi dan telekomunikasi, contohnya seperti internet, televisi, siaran radio dan video atau audio conferencing. Dalam pengelolaannya pembelajaran online diarahkan bagaimana siswa dapat

11 M. Ilyas Ismail, Teknologi Pembelajaran sebagai Media Pembelajaran, Makasar: Cendekia Publisher, 2020), hal. 47

12 Darin E. Hartley, Selling e-Learning, American Society for Training and Development, h. 201

13 Muhammad Fachri, E-learning Sebagai Alternatif Pembelajaran Modern, Jurnal Pendidikan Inovatif Vol. 2, No 1, September (2006), h. 23 
menyerap informasi sesuai dengan topik bahasan, sehingga pengelolaan lebih diarahkan pada proses belajarnya. ${ }^{14}$

Dalam pemanfaatannya e-learning mempunyai peran yang signifikan terkhusus pada aspek pendidikan konvensional yang memiliki keterbatasan ruang dan waktu.E-learning dapat menjadi solusi problematika tersebut karena dengan karaktersitik internet itu sendiri yang dapat menguhubungkan segala sesuatu dengan harga terjangkau sehingga dapat digunakan oleh siapa saja (everyone), dimana saja (everywhere), kapan saja (everytime) dan bebas digunakan (available to everyone). ${ }^{15}$ Pengembangan pendidikan menuju $e$ learning merupakan suatu keharusan agar standar mutu pendidikan dapat ditingkatkan.

E-learning berbeda dengan pembelajaran tatap muka (konvensional) dan memiliki karakteristiknya sendiri, antara lain sebagai berikut: ${ }^{16}$

1. Interactivity (Interaktivitas); tersedianya jalur komunikasi yang lebih banyak, baik secara langsung (synchronous), seperti chatting atau messenger atau tidak langsung (asynchronous), seperti forum, mailing list atau buku tamu.

2. Independency (Kemandirian); fleksibilitas dalam aspek penyediaan waktu, tempat, pengajar, dan bahan ajar. Hal ini menyebabkan pembelajaran menjadi lebih terpusat kepada siswa (student centered learning).

3. Accessibility (Aksebilitas); sumber-sumber belajar menjadi lebih mudah diakses melalui pendistribusian di jaringan internet dengan akses yang lebih luas daripada pendistribusian sumber belajar pada pembelajaran konvensional.

4. Enrichment (Pengayaan); kegiatan pembelajaran, presentasi materi kuliah dan materi pelatihan sebagai pengayaan, memungkinkan

14 Ibid, hal. 206

15 La Hadisi and Wa Muna, "Pengelolaan Teknologi Informasi dalam Menciptakan Model Inovasi Pembelajaran”, Jurnal Al-Ta'dib, vol. 8, no. 1 (2015), h. 125.

16 Rusman, Belajar dan Pembelajaran Berbasis Komputer: Mengembangkan Profesionalisme Guru Abad 21, (Bandung: Alfabeta, 2013), hal. 292 
penggunaan perangkat teknologi informasi seperti streaming video, simulation, dan animation.

Keempat karakteristik di atas merupakan ciri khas e-learning yang menjadikan daya tangkap siswa terhadap materi pembelajaran tidak lagi tergantung pada guru, karena siswa dapat mengkonstruk sendiri ilmu pengetahuannya melalui bahan-bahan ajar yang disampaikan melalui interface situs web.

Adapun salah satu bentuk dari pengaplikasian e-learning ialah pembelajaran berbasis web yang merupakan sebuah pengalaman belajar dengan memanfaatkan jaringan internet untuk berkomunikasi dan menyampaikan informasi pembelajaran, model pembelajaran ini biasa dikenal dengan istilah "web based learning". ${ }^{17}$ Meskipun pembelajaran berbasis web, namun guru atau pengajar bahasa Arab juga harus memperhatikan metode pembelajaran yang diterapkan. Materi yang lengkap tidak dapat tersampaikan dengan baik kepada murid tanpa melalui metode yang tepat. Maka dari itu, guru dituntut untuk menguasai teori-teori pembelajaran yang matang. ${ }^{18} \mathrm{Hal}$ ini diperlukan guru untuk menentukan metode pembelajaran yang tepat untuk murid. Tanpa penguasaan teori pembelajaran, sudah dapat dipastikan bahwa pembelajaran di kelas kurang efektif dan efisien.

Sebagai komponen yang penting dalam pembelajaran, metode memiliki peran yang sangat penting. Bahkan, semua materi yang akan diajarkan guru membutuhkan metode. Metode dibutuhkan untuk menyampaikan materi kepada siswa agar tujuan pembelajaran yang telah dirumuskan lembaga dapat tercapai dengan baik. ${ }^{19}$ Selain itu, metode digunakan untuk memberi gambaran secara menyeluruh ketercapaian tujuan pembelajaran secara sistematis.

17Ibid, hal. 293

18 Tayar Yusuf dan Syaiful Anwar, Metodologi Pengajaran Agama Dan Bahasa Arab, (Jakarta: Raja Grafindo Persada, 1995), h.2.

${ }^{19}$ Abdul Hamid, dkk. Pembelajaran Baḥasa Arab, (Malang: UIN Malang Press, 2008), h.3 


\section{Karakteristik Media Pembelajaran}

Penyajian media pembelajaran perlu mendapat perhatian yang serius. Hal ini dapat membawa dampak yang signifikan dalam proses pembelajaran. Penataan gambar, visual, audio dan lainnya harus mendapat prosi yang tepat agar media yang diciptakan dapat optimal. Karakteristik media yang perlu diperhatikan diantaranya adalah sebagai berikut:

a. Jelas dan rapi, media yang mengandung konten audio, gambar, atau yang lainnya disusun dengan rapi dan sesuai dengan posisinya. Audio atau gambar yang dimasukkan harus jelas agar media yang disajikan informatif.

b. Bersih dan menarik, media yang baik adalah media yang dapat menarik perhatian siswa atau peserta didik. Dengan demikian, siswa dapat lebih fokus dan memperhatikan materi pelajaran.

c. Sesuai dengan sasaran, guru atau pengajar harus memperhatikan pemilihan media yang tepat. Media yang akan digunakan harus sesuai dengan kondisi peserta didik. Kondisi yang perlu diperhatikan dapat berupa kondisi psikologis, jumlah peserta didik, atau keanekaragaman skill yang terdapat dalam satu kelas.

d. Sesuai dengan topik dan tujuan pembelajaran. Hal perlu diperhatikan adalah kesesuaian media dengan materi pelajaran dan tujuan dalam pembelajaran. Guru dan pengajar harus mengkaji tujuan pembelajaran dan menyesuaikan dengan media yang akan digunakan. Kesesuaian tersebut adalah kunci dalam menentuan media pembelajaran yang sesuai dan efektif.

Dalam penyajian media pembelajaran, guru perlu melakukan beberapa evaluasi terhadap media yang dipilih. Hal ini dilakukan untuk mendapatkan informasi yang akurat mengenai pencapaian media yang disusunyang telah disesuaikan dengan indikator yang dirumuskan. Selain itu, evaluasi media ini untuk mengetahui keefektifan dan efesiensi sistem pembelajaran yang akan dilakukan, baik yang menyangkut tentang tujuan, materi, media, materi, 
lingkungan, maupun evaluasi itu sendiri. ${ }^{20}$ Secara khusus, evaluasi tersebut bertujuan untuk:

a. Mengetahui tingkat efesiensi media dalam pembelajaran.

b. Mengetahui kekurangan dalam media sehingga guru atau pengajar dalam menyempurnakan.

Evaluasi media membelajaran dapat dilaksanakan dengan test atau dengan observasi atau pengamatan. Dalam pelaksanaan evaluasi media pembelajaran, ada beberapa objek yang dapat dievaluasi. Bebera hal yang merupakan objek evaluasi adalah sebagai berikut:

a. Input, meliputi gambar, audio, video, atau konten yang terdapat dalam media pembelajaran.

b. Tranformasi, meliputi kesesuaikan media pembelajaran dengan materi dan tujuan pembelajaran yang telah di tetapkan.

c. Output, yaitu media pembelajaran yang telah disusun secara keseluruhan.

\section{Desain Taajul Lughati: Media Pembelajaran Bahasa Arab Online Berbasis Website}

Tahap desain Taajul Lughati dimulai dengan mengumpulkan data literatur dari berbagai buku, jurnal, atau buku-buku ajar yang dipakai dalam pembelajaran bahasa Arab. data yang diperoleh, kemudian di analisa untuk mendapatkan informasi sehingga desain Taajul Lughati selaras dengan tujuan pembelajaran bahasa Arab di Pusdiklat UNIDA Gontor. Peneliti melakukan reduksi data dari berbagai data yang telah dikumpulkan. Dari proses tersebut, peneliti mendapatkan data-data yang sesuai dengan pembelajaran di Pusdiklat UNIDA Gontor.

Setalah mendapatkan data-data yang cukup, peneliti membuat desain rancangan web yang akan di gunakan. Dalam hal ini, peneliti bekerja sama dengan mitra untuk merancang desain web yang telah direncanakan. Hal-hal

${ }^{20}$ Ismail Suwardi Wekke, Pembelajaran Bahasa Arab di Madrasah, (Sleman: Deepublish, 2016), h. 147 
penting yang perlu dipersiapkan peneliti untuk membuat desain web pembelajaran bahasa Arab adalah sebagai berikut:

a. Mekanisme rekrutmen dan pendaftaran peserta didik yang akan mengikuti diklat. Data ini diperlukan untuk mendesain beranda pendaftaran peserta diklat.

b. Warna-warna yang akan muncul di laman web. Warna mempunyai peranan penting, karena tampilan web yang menarik akan memberikan support kepada siswa untuk menumbuhkan semangat belajar dan mengikuti diklat.

c. Pemilihan materi. Materi diklat diinput berdasarkan kurikulum pembelajaran bahasa Arab di Pusdiklat UNIDA Gontor, khususnya untuk siswa pemula. Materi ini perlu disesuaikan dengan bebera hal, misalnya kesesuaian umur, minat, level, dan lainnya.

d. Pemilihan media pembelajaran. Media pembelajaran yang digunakan untuk pembelajaran bahasa Arab secara online harus menarik. Karena dalam prosesnya, guru tidak bisa bertatap muka secara langsung dengan siswa. Maka, media mempunyai peranan yang sangat penting.

e. Pelaksanaan evaluasi pembelajaran. Evaluasi ini sangat menentukan untuk melihat keberhasilan diklat. Nilai akhir siswa nantinya akan digunakan untuk program perbaikan sistem sehingga program ini dapat berjalan secara efektif dan efisien.

Taajul Lughati merupakan media pembelajaran bahasa Arab berbasis website yang didesain sesuai dengan kurikulum pembelajaran bahasa Arab di Pusdiklat UNIDA Gontor. Taajul Lughati menyajikan materi pembelajaran bahasa Arab tingkat dasar atau mubtadi'in yaitu setingkat dengan siswa MI dan MTS. Materi ajar terdiri dari tiga materi yaitu:

a. Durushullughah al-arabiyah

b. Maharatul qira'ah

c. Maharatul istima'

Materi-materi tersebut akan disajikan dengan berupa gambar, audio, video, teks yang menarik. Hal ini dirancang untuk peserta diklat yang baru belajar bahasa Arab. Oleh karena itu, program ini harus dirancang dengan konten-konten yang menarik. 


\section{Desain Taajul Lughati Sebagai Media Pembelajaran Bahasa Arab Online}

Desain media yang telah dikaji menggunakan Moodle. Benyuk desain yang telah disusun adalah sebagai berikut:

\section{Desain Halaman Utama atau Beranda}

Halaman beranda merupakan halaman utama yang ditampilkan pada saat pertama kali website dibuka atau dijalankan. Dalam halaman ini mencakup berupa pengisian identitas untuk penggunanya. Untuk masuk pada web Taajul Lughati diperlukan data peserta beserta email pengguna. Peserta dapat bergabung dalam pembelajaran online dengan mendaftar di halaman ini.

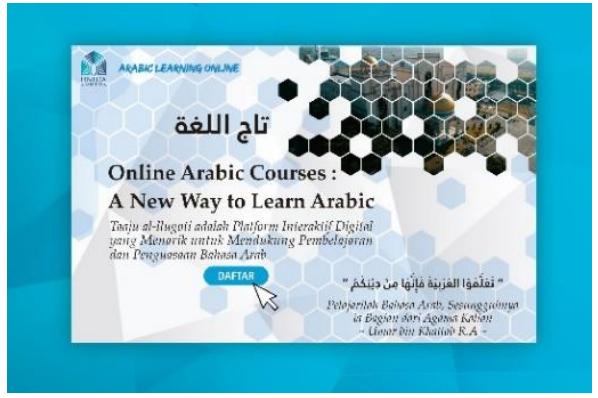

Gambar1: Tampilan awal

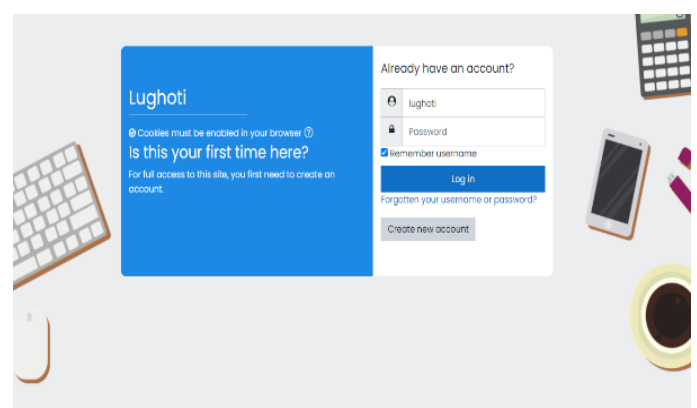

Gambar 2: Halaman masuk

\section{Menu Materi}

Pada menu pelajaran ini peserta didik dapat mengakses berbagai materi. materi yang telah disiapkan adalah materi yang ada dan diajarkan di Pusdiklat UNIDA Gontor. Dalam halaman ini terdapat tiga pelajaran yang dapat dipilih oleh penggunanya antara lain ialah pelajaran durushullughah alarabiyah, maharatul qira'ah dan maharatul istima'. Dalam menu ini, web telah didesain sedemkian rupa sehingga siswa mengikuti dengan baik. Peserta diklat diharuskan untuk menyelesaikan materi-materi dengan berurutan. Hal ini bertujuan untuk proses penilaian pada tahap akhir. Siswa hanya dapat melanjutkan materi selanjutnya apabila telah menyelesaikan materi sebelumnya. Materi tersebut disajikan dengan berupa video, gambar, teks dan audio yang telah didesain sehingga dapat meningkatkan minat serta motivasi siswa dalam belajar bahasa Arab 


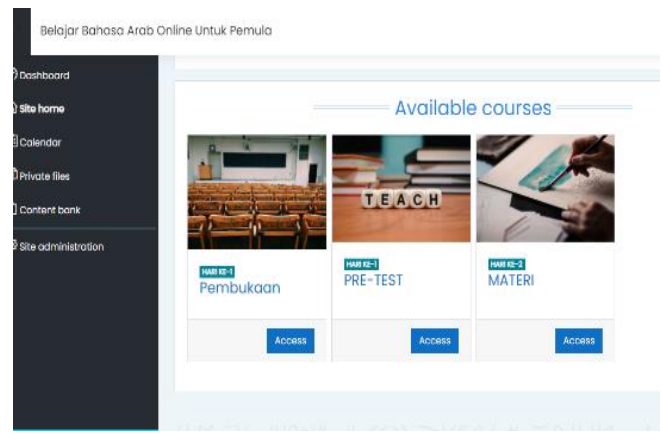

Gambar 3: Beranda

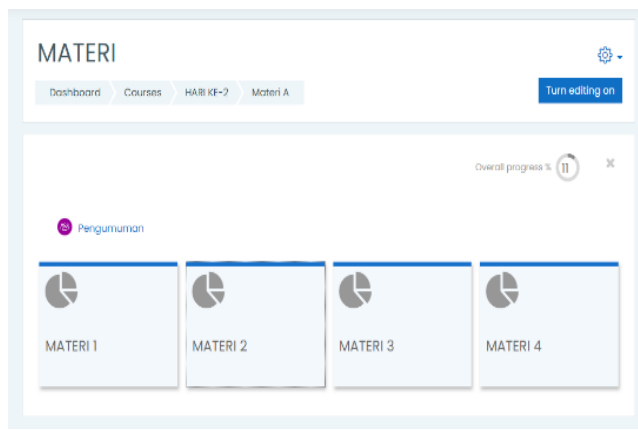

Gambar 4: Pelajaran

\section{Materi Pelajaran}

Materi Pelajaran yang telah disisapkan adalah 3 materi pelajaran yang ada di Pusdiklat UNIDA Gontor. Materi tersebut adalah:
a. Durûs al Lughah Al-Arabiyah
b. Mahārat al Qirā'ah
c. Mahārat al Istimä'

Materi tersebut disajikan dalam ilustrasi media gambar untuk mempermudah peserta diklat memahami kosa kata baru. Materi juga didukung dengan beberapa audio dan video agar media lebih interaktif dan dapat menjadi daya tarik tersendiri. Berikut adalah contoh media gambar yang disajikan dalam web:

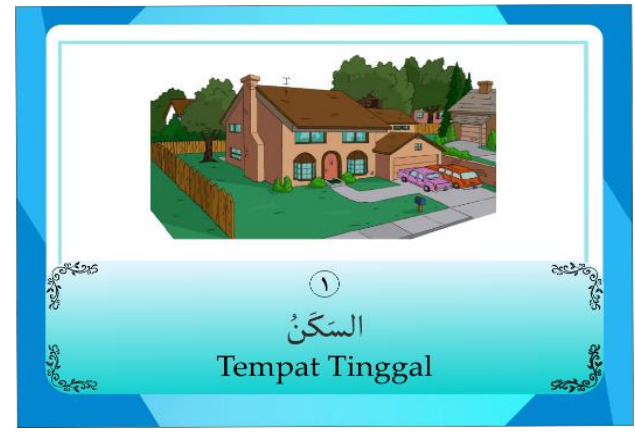

Gambar 5: Materi Durusul Lughah

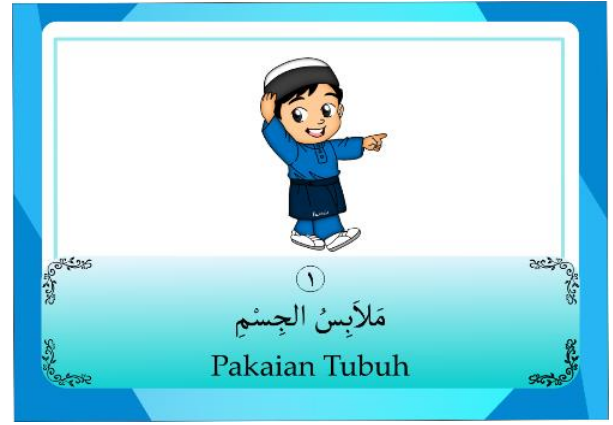

Gambar 6: Materi Muthala'ah 


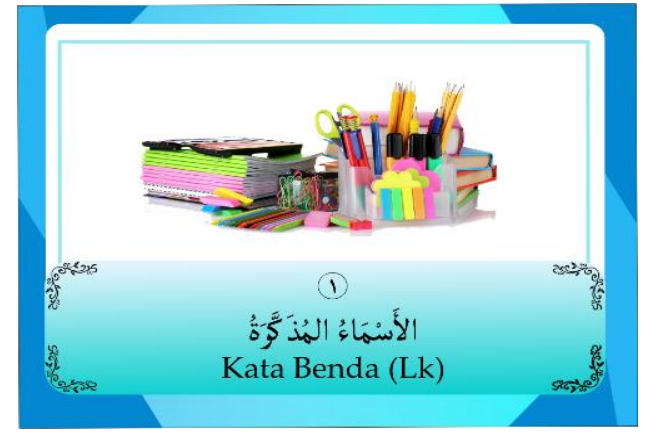

Gambar 7: Materi Maharatul Istima'

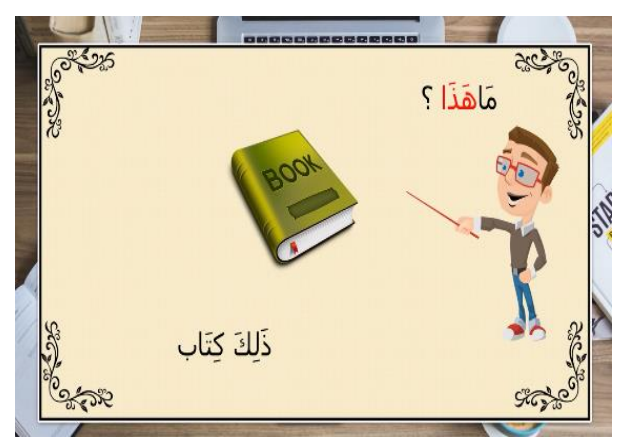

Gambar 8: Materi dengan video

Untuk memastikan peserta didik memperhatikan dengan baik, maka dalam sesi pembelajaran, media ini menyediakan kuis yang berupa soal latihan ringan yang dapat dikerjakan peserta. Soal tersebut adalah soal objektif True or False. Soal ini ditujukan untuk memastikan pemahaman peserta dan memastikan bahwa peserta benar-benar memperhatikan dengan baik.

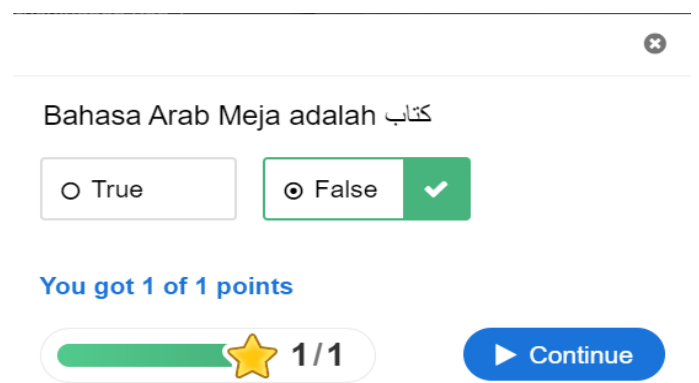

Gambar 9: Saol latihan

\section{Evaluasi}

Evaluasi akhir dilaksanakan setelah pembelajaran selesai. Evaluasi ini dapat menggunakan beberapa alternatif media online, dapat berupa google form, Kahoot, Quizizz, atau yang lainnya dengan menyertakan link dalam kolom web. 
Dalam implementasinya, web akan di ujicobakan kepada mitra sebagai peserta didik. Hal ini dilakukan untuk mengetahui efektifitas dari media pembelajaran ini. Langkah-langkah yang akan ditempuh peneliti selanjutnya adalah sebagai berikut:

a. Bekerja sama dan sosialisasii dengan beberapa pihak seperti dengan PUSDIKLAT dan program studi Pendidikan Bahasa Arab Universitas Darussalam Gontor dalam memenuhi fasilitas yang dibutuhkan.

b. Membuka pendaftaran. Program pembelajaran akan terbagi menjadi dua jenis, satu terbuka untuk umum dan yang kedua untuk instansi pendidikan yang telah melakukan MoU dengan Universitas Darussalam Gontor. Dengan slogan "Dari UNIDA Untuk Indonesia Menyapa Dunia" website Taajul Lughati ini akan dikembangkan menjadi inovasi media pembelajaran yang menckakup di dalamnya program pembelajaran.

c. Pelaksanaan program pembelajaran dengan menggunakan website Taajul Lughati sebagai media yang akan digunakan selama program berlangsung. Pelaksanaan program berjalan selama 12 hari yang terdiri dari 3 pelajaran yaitu durushullughah al-arabiyah, maharatul 'istima' dan maharatul qira'ah. Pada setiap pelajaran akan tersedia 10 materi pokok di dalamnya dengan bentuk video, audio dan teks dan gambar yang menarik. Pelaksanaan program terdiri dari pembukaan, pretest, pengaksesan materi, refleksi pembelajaran, posttest, dan penutupan.

d. Evaluasi. Evaluasi dilakukan dengan tujuan untuk mengetahui seberapa efektif program ini berjalan dan untuk mengukur seberapa jauh pemahaman dan capaian belajar siswa dalam meningkatkan kemampuan bahasa Arab dengan hadirnya website pembelajaran bahasa Arab Taajul Lughati. 


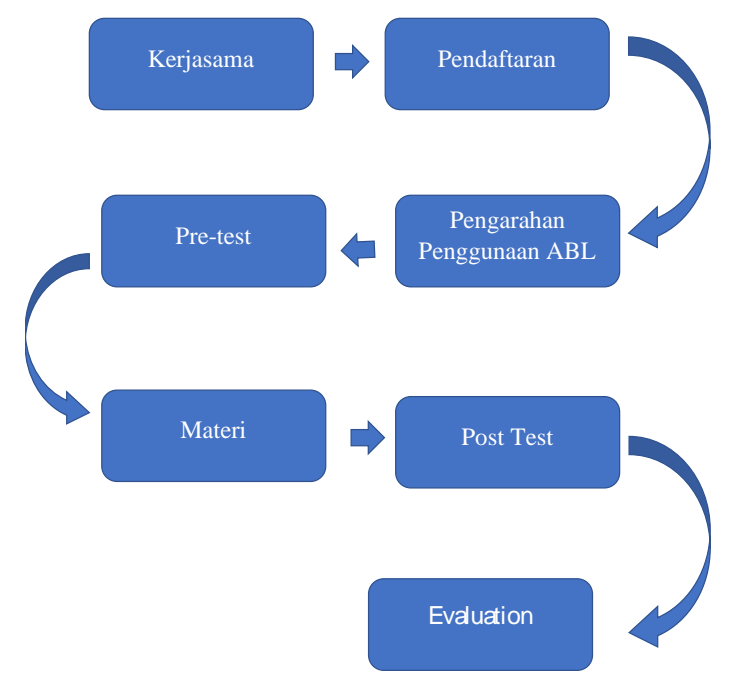

\section{Simpulan}

Kegiatan pembelajaran E-Learning mengutamakan komunikasi internet. Maka dari itu, media pembelajaran yang menggunakan fasilitas internet dan disampaikan jarak jauh merupakan alternatif yang mempunyai peran penting dalam kesuksesan pembelajaran jarak jauh. Taajul Lughati merupakan sebuah inovasi media pembelajaran bahasa Arab berbasis website. $W e b$ ini disusun dengan basis moodle. Dalam media ini mengandung konten materi-materi pembelajaran yaitu durushullughah al-arabiyah, maharatul qira'ah dan maharatul 'istima'. Dalam penyajian materi tersebut, media ini didukung dengan media gambar, video animasi, dan audio. Kendala yang dialami peneliti adalah mencari mitra untuk dijadikan peserta untuk uji coba produk dalam langkah selanjutnya.

\section{Daftar Pustaka}

Amrullah, Ahmad Fikri. Manajemen Kurikulum Pembelajaran Bahasa Arab, Jakarta: Kencana. 2021

Fachri, Muhammad. "E-learning Sebagai Alternatif Pembelajaran Modern" Jurnal Pendidikan Inovatif Vol. 2, No 12006 
Falahudin, Imam. "Pemanfaatan Media Pembelajaran" Jurnal Lingkar Widyaiswara, Vol. 1 no. 42014

Firdausia, Amalia, dkk. "Pengembangan Media Pembelajaran Bahasa Arab Berbasis Web Offline", Pendidikan Islam dan Keguruan, vol. 2, no. 2. 2020

Hermawan, Acep. Metodologi Pembelajaran Bahasa Arab, Raja Grafindo Persada. 2014

Hamid, Abdul, dkk. Pembelajaran Bahasa Arab, Malang: UIN Malang Press. 2008

Ismail, M. Ilyas, Teknologi Pembelajaran sebagai Media Pembelajaran, Makasar: Cendekia Publisher. 2020

Maemunawarti, Siti, dkk., Peran Guru, Orang Tua, Metode,dan Media Pembelajaran: Strategi KBM di Masa Pandemi Covid-19, Serang: 3M Media Karya Serang. 2020

Rambe, Pangadilan. "Pengembangan Aplikasi Pembelajaran Inovatif Dalam Pembelajaran Bahasa Arab Berbasis Web", Arabi: Journal of Arabic Studies, vol. 4, no. 1. 2019

Rusman. Belajar dan Pembelajaran Berbasis Komputer: Mengembangkan Profesionalisme Guru Abad 21, Bandung: Alfabeta, 2013

Sadiman, Arief. Media Pendidikan Pengertian, Pengembangan dan Pemanfaatnnya, Jakarta: Rajawali, 2015

Sadiman, Arief S. Dkk. Media Pendidikan: Pengertian, Pengembangan, dan Pemanfaatannya, Jakarta: Raja Grafindo Persada, 2015

Sanjaya, Wina. Perencanaan dan Desain Sistem Pembelajaran, Jakarta: Kencana, 2017 
Wa Muna, La Hadisi. "Pengelolaan Teknologi Informasi Dalam Menciptakan Model Inovasi Pembelajaran (e-learning)” Jurnal Al-Ta'dib Vol. 8 No. 1 2015.

Wekke, Ismail Suwardi. Pembelajaran Bahasa Arab di Madrasah, Sleman: Deepublish. 2016

Yaumi, Muhammad and Muljono Damopolii, "Model Integrasi Teknologi Informasi dan Komunikasi dalam", Al-Musannif: Journal of Islamic Education and Teacher Training, vol. 1, no. 2. 2019

Yusuf, Tayar dan Syaiful Anwar, Metodologi Pengajaran Agama Dan Bahasa Arab, Jakarta: Raja Grafindo Persada. 1995

Zulhannan. Teknik Pembelajaran Bahasa Arab Interaktif. Jakarta: Raja Grafindo Persada, 2014 
Hani'atul Mabruroh et al: Tājul Lughati Desain Media Pembelajaran Online

Jurnal Al Mi'yar Vol. 4, No. 2 Oktober 2021

Homepage https://jurnal.stiq-amuntai.ac.id/index.php/al-miyar 